\title{
FISHERMEN ECONOMIC BALANCING OF SOCIETY'S WELFARE (Critical Study of fisherman in Pati and Rembang)
}

\author{
Arpangi, Sukarmi, Denny Suwondo \\ Faculty of Law, UNISSULA, Semarang \\ denny@unissula.ac.id arpangi@unissula.ac.id sukarmi_sh@yahoo.com
}

\begin{abstract}
The marine affairs and fisheries is one that has certain mission. Mission inception fishery ports fish in the area of Pati or Rembang the basically is to welfare goldfish the scope of starch fishermen. In the facts that's not yet fully realized so that solving the problem. Invite number 16/1964 not in accordance local conditions were pestered feel earn a living land due to feel the provisions of box or restricted becouse autonomous regional. The basis of the law of the Regional Regulations respectivelely but not progressing smoothly fisherman using fixed tribal law due to the county needed local. The field of marine affairs and fisheries is one that has certain mission. Inception mission in fishery ports in Pati or Rembang is basically concerned to welfare goldfish the scope of starch society fishermen. The fact is the implementation is not yet fully realized, so that it can solve the problems. Invite number 16/1964 was not in accordance with local conditions and were pestered feel earn a living land due to feel the provisions of box or restricted because of autonomous regional. The basis of the Regional Regulations is respectivelely but it is not progressing smoothly. The fishermen use fixed tribal law due to local demand.
\end{abstract}

\section{Keywords : Fisherman; Juragan and Pandega (Javanese Lng.)"; Results Balancing.}

\section{A. INTRODUCTION}

National fisheries developed the policies and programs on the basis of current issues and/or problems encountered and taking into account the influences of the ever-changing internal and external environment. The policy of fish farming development is different from the current policy which is focused on optimizing and controlling the utilization of fish resources as well as improving the quality and value added of fishery products in order to improve the welfare of the fishermen community.

The fact now in the sharing must be based on the Regional Regulation, but until now the Regional Regulation has not set about the profit sharing of the fishermen. Hence, the fishermen go to sea still use the basis of the agreement that is based on customary law of each region. The basis of the agreement based on local customary law is actually a lack of justice in the distribution of fish catch between fishermen with "Pandega (Javanese Lng.)".

Pandega or cultivators are just "sendiko dawuh (Javanese Lng.)" or obedient course if not so he did not get any results, because they do not have their own capital. Whereas the daily necessities must be met both for the whole family and the stock of lunch to go to sea. This condition creates an imbalance that is increasingly widened among the fishermen, thus impacting far from prosperous.

The problem that arises is how the effort must be done to overcome the inequality between the "Juragan (Javanese Lng.)" of fishermen with 
Pandega or cultivators to achieve justice and balance in dividing the fish catch so that it can prosper the community (Pandega fisher or cultivator). In addition, there is also transparency in provision of supplies with the results obtained. The legal basis used remains the customary law that prevails in its environment.

On the other hand, this research used a theoretical framework with an approach of the legal arrangement of profit sharing agreements seeks to be maximized for the community welfare, so that the balance between the rights and obligations of the parties can be intended as a motivator to be more active in fishing activities under any circumstances. This view is influenced by the Utilitarian theory of Jeremy Bentham, it is a principle that tells everyone to do as much as possible to produce the greatest happiness of the greatest number. This theory is a philosophy of Utilitarian theory that defines truth and justice is an action associated with a contribution that considers its ultimate aim. In this theory, law is established to provide benefits and happiness to most individuals in society, so the final findings of legislation are to be expected for the greatest happiness. ${ }^{1}$

The profit-sharing system implemented by the fishing communities (Rembang and Pati District) still implements the results according to local customary law, so that the law or Regional Regulation that should be the basis of law is neglected, thus adversely affecting the community. This theory is expected to be able to make the concept of proposed profit sharing policy in

1 Abdul Salam, 2011, Filsafat Hukum, Perspektif Sejarah, Jakata, PTIK, p.52 in the Kholis Roisah, Dinamika Perlindungan HKI in Catatan Global, p.14. accordance with the expectations or at least can be applied the existing Revenue Act accompanied by improvements in the policy required, so that the welfare of society can be achieved optimally. If we look at the customary law user community, the main characteristic must know how the relationship between individuals and society in an environment. according to John Locke, it is based on the state of nature that man has the inviolable rights of nature, namely the right to life, the right of freedom, the right to property and the right to happiness. In contrast to Hobbes's natural state, there is a state like a jungle, then Locke is in a safe, peaceful and understandable state of nature between individuals, none of whom can diminish, except the organization that governs the life of society. ${ }^{2}$

The Civil Code regulates the legal basis of the treaty, as provided for in Article 1320 BW that for the validity of the treaty is based on four conditions, namely: agreement to those who commit it, the ability to make an engagement, a certain matter, and a lawful cause. Article 1338 Civil Code: all legally-made agreements shall apply as laws to those who produce them and the agreements shall not be withdrawn apart from the agreement of the parties, or for reasons which the law otherwise suffice. Article 1337 of the Criminal Code says: Anything is become forbidden, if any agreement or act is contrary to the law or it is contrary to morality or public order ${ }^{3}$. If so then

2 Mariam arus Badrulzaman, 1981, Pembentukan Hukum Nasional dan Permasalahannhya (Kumpulan Karangan), Alumni, Bandung, p.111112.

3 Soebekti dan Tjitrosudibio, 1983, Kitab Undangundang Hukum Perdata, Pradnya Paramita, Jakarta, p.307. 
the agreement made by Pandega or cultivator fishermen is actually done in accordance with the habits ${ }^{4}$ that occur between Pandega or cultivators with Juragan, but Pandega do not know for sure. From a sociological point of view, this agreement is actually not against the law, but philosophically it should be based on Pancasila values like the fifth precept of Pancasila. To create a prosperous and just Indonesia, the reference is Pancasila as the visionary values ${ }^{5}$, which function integrative. It can guarantee the unity of pluralistic in Indonesia. Moreover, it is more unique because Pancasila becomes one of the outer admiration of Indonesia, it has the function of uniting society and region vast archipelago with various ethnic, cultural, linguistic and religious backgrounds ${ }^{6}$. This is also found in the preamble of the fourth paragraph of the 1945 Constitution.

\section{B. DISCUSSION}

\section{The Legal for Fishermen}

Law No. 16 of 1964 is expected to be able to improve the living standards of fishermen, it is seen still not optimal in relation to the presence of Regional Autonomy. Thus the legal basis for fishermen is using the basis of their respective Regional Regulations. The facts revealed are different from the expected conditions, although there has been a legal basis used for fishing and revenue sharing, but in reality the fishermen continue to use the local

4 Based on the prevailing habits in the community around from the ancestors. The results of interviews with the fishermen and shipbuilders.

5 Syahrial Syarbaini, 2011, Pendidikan Pancasila (Implementasi Nilai-nilai Karakter Bangsa), Ghalia Indonesia, Jakarta, P.2.

6 Ibid.p.2. customary law rather than the law or Regional Regulation. This condition is triggered by ineffective supervisory function, misleading policy, not transparency of related officials. So a good initial goal changes as if being or impacting into an organized blackmail.

This social reality contradicts the prevailing laws and seems to be a symptom of impeding implementation. Many factors have caused Indonesia in general to remain in a lagging position, there has not been a true development vision and implemented on an ongoing basis. It may be a step to be taken by mutual agreement with no high emphasis so that the fishermen are able to move, strive, take the initiative to convey hidden desires. Further, even if it is possible, make effective of the small cooperatives within the scope of the relevant Regency TPI and require fishermen and middlemen is obliged to become a member of the Cooperative.

Specifically TPI Tasikagung there are cooperatives in charge/function as: (1) managing fish resources responsibly; Encouraging fishermen to auction their fish in TPI, (3) encouraging fish traders to participate actively in the fish auction process in TPI; (4) Providing basic facilities, supporting facilities, facilities and infrastructure to support the smooth implementation of fish auction in TPI; (5) Creating a sense of security and comfort to the actors of production (fishermen) and actor of fishery products (fish trader/processing entrepreneur) before, during and after the tender process; (6) Maximizing Local Original Revenue 
earned on the use of facilities and infrastructure of existing TPI by fishery business actors.

Law No. 16 of 1964 aims to improve the living standards of fishermen. Facts revealed different conditions, because the local customary law is more concern on the Act. This condition is triggered by ineffective monitoring function, misleading policy, non-transparency of the parties concerned. Hence, a good initial goal changes as if being or impacting into extortion. This social reality contradicts the prevailing laws and seems to be a symptom of impeding implementation.

Many factors cause Indonesia to remain left behind, there is no true development vision and implemented on an ongoing basis, lack of mastery and application of science and technology ${ }^{7}$. Even the government policy limit the subsidized diesel fuel, even this makes the revenue share of fishermen workers is getting smaller. 8

The research undertaken has a specific target of making the Proposed Concept of a Fair Share Equalization Policy balanced for Understanding of the elements of the treaty, the rights and obligations of the parties, the nature of the agreement, and the effects of the Covenant. Profit Sharing Fisheries are expected to reduce poverty significantly, it has not yet achieved well, so that appropriate steps are needed. Furthermore, the inventory, identification and investigation of cases of injustice to find the obstacles

7 Sayogyo, Cendekiawan Pembela kaum lemah, Gatra No.20 Tahun XVIII, 22-28 March 2012, p.32.

8 Kompas, Saturday on 25 February 2012, p.22. of Pandega and Juragan, where between the two fishermen occur abuses and injustice in the distribution of the results in an effort to obtain a fair economic welfare. Historical/sociological approach with structural functional theory to the fish catch results was used, it found that the life of fisherman is increasingly difficult, the debt to the Juragan increases. The researchers made concepts for concrete results in the concept of agreement based on the Civil Code, about the definition of an agreement, the validity of the agreement, the conditions to be met of the agreement, the effects of the agreement and the invalid agreement, the agreement is null and the agreement is void.

Structural Functional Theory emphasizes order and ignores conflicts and changes in society. The main concepts are function, dysfunction, latent function, manifest function and equilibrium. The theory that includes the concept of equilibrium is very important to measure the extent level of equilibrium in dividing the results of fishing by Juragan and Pandega. It is necessary to know that the system for the results implemented by the fishermen community in this city is still applying for the results according to local custom law, so that the law that should be implemented optimally is neglected. The condition is very detrimental to society. This theory is expected to be able to make the concept of profit-sharing in accordance with the expectations or at least can be applied to the existing Law Sharing with improvement on the policy required, so that the welfare of society can be achieved. 
The elements of the agreements are: a) the existence of legal subjects; b) the existence of a legal object; c) there is an agreement; d) there is a healthy, physical and mental ability or not below ability; e) the existence of a lawful cause. As for the validity of the agreement based on Article 1320 of the Civil Code where it takes four conditions, namely: agree those who bind themselves, the ability to make a commitment, a certain thing, a lawful cause.

Article 1338 of the Civil Code stipulates that all legally-made agreements shall apply as laws to those who produce them and the agreements shall not be withdrawn other than by mutual agreement, or for reasons which the law expresses sufficient. In this condition, the sharing result for Pandega is actually there has been an agreement ${ }^{9}$ between Pandega and Juragan. So, if viewed from the sociological point of view, this agreement is not contradictory to the law, there is only a lack of fairness and balance, because Pandega are more often harmed, but they are just silent as if powerless to face Juragan.

The legal basis underlying the establishment of the Marine and Fisheries Center in Rembang Regency consists of ${ }^{10}$ :

9 Sholehudin, interview on 3/8/2013 with the crew of fishermen in Kab.Pati, according to him that the agreement in question is because this work is an inheritance from the ancestors, then this agreement also has existed or is assumed to have existed since the first so that it is considered hereditary.

10 Handbook of Technical Implementation Unit of Fishery Business Management and Development, Rembang Regency Government Marine and Fishery Service Office.
1. Law Number 31 Year 2004 concerning Fisheries as amended by Act Number 45 of 2009 concerning Amendment to Law Number 31 Year 2004 regarding Fisheries.

2. Government Regulation No. 38/2007 concerning the Division of Government Affairs between the Government, Provincial Governments and District / Municipal Governments.

3. Regional Regulation of Rembang Regency Number 2 Year 2008 About Government Affairs which become Authority of Regional Government of Rembang Regency.

4. Regional Regulation of Rembang Regency Number 4 Year 2009 About Management of Fish Auction Place.

5. Regional Regulation of Rembang Number 13 Year 2011 concerning Service Business Levy.

6. Regent's Regulation no. 40 Year 2012, Implementation Guidance of Fish Auction Place.

To further empower the potential of fishermen, the fishermen in Pati Regency have been trying to provide fish empowerment training conducted in various places such as:

a. Kalikalong Village main Hall, Tayu District.

b. Tambahmulyo Village, Gabus District

c. Godo Village, Winong District.

Target of Participants of Development is trader and fish processor in Pati Regency consists of:

a. Kalikalong village as many as 40 traders and fish processors;

b. Tambahmulyo village as many as 40 traders and fish processors; 
c. Godo village as many as 40 traders and fish processors;

In the framework of the implementation of trader ball and fish processing activities were given by lecture and milkfish processing practice. The material of traders and Fish Processing were presented by the Head of Fishery Division of the Office of Marine and Fisheries of Pati Regency, the vision and mission of the Department of Marine and Fisheries Regency is as the main center of fisheries production in Central Java through the management of marine and fishery resources efficiently and sustainable for the people's prosperity.

Matters to be considered in development in the field of fisheries are as follows:

1. Infrastructures in the field of fisheries are ready, for example: the construction of pond irrigation, construction of coolroom/cold storage, and others.

2. Increasing the quality of human resources to carry out activities

3. The existence of funding facilities (capital).

4. Development in the institutional field with the formation of groups (groups of fishermen, cultivators, processors and women fishermen). Breeding activities and fish processors have an important role in fisheries development as a support to increase fishery production.

The objectives and targets of coaching are to support the successful achievement of fisheries development especially in encouraging the utilization of fish catch potential by diversifying the processed fish products and increasing the quality of fishery products is very influential in marketing.

The potential of fish ponds in Pati Regency especially milkfish production is very big, therefore, the traders and fish processing in Pati Regency in order to utilize milkfish production not only sold in fresh form, but also apply new technology (by utilizing one type of fish raw material milkfish) it can be made various forms of processed fish. For example milkfish can be made into abon fish, otak-orak, presto, milkfish, bredead, and others. Thus it will be able to increase income for traders and fish processors because the selling price is bigger than fresh milkfish.

Traders and fish processors in order to be successful in doing business, they must have these characteristics:

1. Ductile;

2. Patience;

3. Not easily give up;

4. Not easily discouraged;

5. Pray.

\section{Briefing from Processing and Marketing Division}

Fish have excellent sources of protein, fats, vitamins and minerals that are needed by the body. The main advantage of protein in fish lies in the completeness of its easily digestible amino acid composition. Fish also contains unsaturated fatty acids (omega 3 ) which is useful for the health and brain development of the baby for the potential of intelligence, for it is recommended to the mothers that every day always serve fish dishes for the family, 
because many fish will conserve their health.

\section{The Material of Milkfish Mtrips} Thorns. into two types:

Basically fish processing is divided

1. Modern processing: processing done with modern technology, such as freezing/cold storage and canning.

2. Traditional Processing: Processing using traditional equipment such as processing of pindang, salting, curing, making of trasi, cracker, etc.

The requirements of good processing are:

1. Fish raw materials: fresh with the characteristics of the scales are still firmly attached, the meat is bright red, chewy, bright eyes and there is still mucus along the body.

2. Water: clean with colorless features, tasteless and odorless.

3. Equipment: anti-rust and clean (stainless steel).

4. Preservatives: natural and permitted by the government (salt and ice).

5. Cold chain: throughout the process fish should be placed at cold temperatures (given ice).

In the fish processing, known diversification, that is a fish raw material can be processed into various kinds of processed products. Things to note by beginners in fish processing business are:

1. Following the market share.

2. Do not give up.

3. Ductile.

4. Paying attention to quality (quality and cleanliness).

5. Timeliness (trust in customers).
Steps to make milkfish without thorns:

1. Prepare fresh milkfish.

2. Prepare equipment consisting of:

a. cutting board

b. Small bowl (water content for washing).

c. Tweezers.

d. Plastic basin (as a small bowl to keep water from spreading).

e. Basin (place of milkfish).

3. Ways:

a. Remove the milkfish scales (pulled up opposite).

b. Remove the scales of other parts.

c. Wash milkfish.

d. The process of cleavage of milkfish starts from behind the bottom fins (do not let about the main thorn).

e. Divide the milkfish up to the head (back) and do not get hit by bile.

f. Clean the bowels, gills, black membranes.

g. Clean with running water.

h. Remove large thorns, caught, pulled upward.

Disposal phase in milkfish thorn:

a. The removal of thorns in the abdomen is 22 spines (relatively easy).

b. Disposal of thorns in the middle as much as 12 spines (1/4 part of the top of the milkfish down) thorns are small, straight, bottom, branched and relatively easily removed.

c. Check with palpable (if there is still a thorn left behind will be felt). 
d. Disposal of thorns on the bottom tail as many as 14 pieces.

e. The blade is reversed so that the thorn does not break (from bottom to top).

f. Knives on $1 / 4$ of the fish, then stops (meat is pressed, so as not to get ripped off).

g. Disposal of the spine from bottom to top (head to) as much as 42 starts from the base of the tail. The meat is pressed towards the head.

h. After all the thorns were pulled out, the milk washed.

i. Packaging and immediately stored in the freezer.

The price of milkfish without thorn can reach $2 x$ the price of fresh milkfish in the market. For example for fresh milkfish prices 20,000 (4-5 milkfishes) then the price of milkfish without thorn reach 40,000 . In the brochure coaching that is divided to participants other than the recipe of milkfish without the thorns, there are also recipes for fish crackers and fish balls. Participants can try in their own home due to the limited time.

Tips for marketing the products of processed fish for beginners are:

1. Family.

2. Posyandu.

3. RT/RW

4. Kelurahan/village

5. Sub-district

6. Shop.

7. Restaurant.

8. Places to eat in the district.

Terms of application for
assistance for fish processing
business actors are:
business actors are: a. Group of at least 20 persons (various products can be processed, because the government can only provide assistance for non-individual groups).

b. Proposal.

c. Help should be utilized.

d. Responsibility

\section{Cases of identified injustice}

In the case of injustice or a case which deviates from the provisions of the Circular Letter but it is permitted or legalized by an officer with the permission of an unspoken institution/service. This is an aberration, but after the researcher asked for help from the PPI Bajomulyo Officer it was conditional. There was a negative side and a positive side; the positive side is that for the Purse Sein Freezer vessels that go to sea, given the opportunity to do without auction by giving a levy that have been determined that is equal to $2.85 \%$ and fish directly into the freezer storage also without any weighing the results of the sea. Under these conditions the positive side is aimed and functioned to fish quickly secured by putting into freezer and this is precisely the undamaged fish (to secure/maintain the quality of the fish catch). So that it can be directly taken to another area/outside the city to be sold with the fresh condition.

However, it can also be a negative side that the fish that came out of the Purse Sein Vessel is not weighed so that it cannot be known in advance, it cannot be known for certain, how heavy the fish, any type of fish, these things cannot be known certainty. And this is detrimental to TPI and Pandega, because the 
retribution is not in accordance with the actual amount and even the price of the fish catch is not separated according to its type, eventually all types of fish are generalized and this is detrimental to the fisherman and the amount of retribution. Whereas in Section Seventh Regional Regulation No. 4 Year 2009 Rembang Regarding Management of Fish Auction Sites, particularly the procedure of Collection/Levy Article 16 states "Retribution levy cannot be encouraged." 11

Perhaps this this is a deviation step undertaken by Juragan to seek greater profits in addition to the fish catch immediately sold. On the other hand, retribution will be unfair, because it does not know the weight of the fish and it is only based on estimates, what kind, size, price estimate should not be known for certain, and this is a form of deviation but it also benefits certain parties.

\section{Investigating the injustice cases $^{12}$}

In an effort to know whether in the distribution of proceeds from these fishermen has been said to be fair or not, then we looked directly on the field. Where in doing the distribution of the results of fishermen was based on mutual agreement in addition based on the Regulation No. 13 of 2011 on Business Services Levies by Regulation No. 40 of 2012 Regarding Guidelines Implementation of Fish Auction Place. If required from the Local Government Regulation, the

11 Regional Regulation Number 4 Year 2009 of Rembang Regency About Management of Fish Auction Sites..

12 Interviewed with Misdi, the Pandega fisherman on August 19, 2013 implementation of auction or distribution of proceeds from the fishermen has been in accordance with the provisions and agreements. On the other hand, there is an irregularity, where irregularities are referred to as local government policies of "acquisition" or "omission" acts that are ostensibly approved by the government.

For example:

1) A Boardman obtained part of the fisherman is two part of the agreement. Then, the sale of the fish must be sold through the auction at the local fish auction site, while the TPI in paying the fish auction results to the fishermen took a long time. Whereas the time to go to sea requires a considerable cost, while the payment from TPI has not been given. The time delay of this payment becomes a serious problem for the fishermen, whereas the traders before the auction must be deposited funds to TPI. How to solve it, but finally taken a step or policy from Ship Board where part of them is sold outside TPI in the hope of fund obtained can to help give trader for fisherman who want to go to sea.

2) In other cases such as the Pourse Seine ship that came to sea after 3 (three) or more so come directly inserted into place Freezer without having separated fish catch and weighed first, so it cannot be known type of fish. This is an aberration but permissible.

A variety of excuses, among other are: 
a. To speed up the circulation of fish;

b. To keep the quality of the fish fresh and not decompose quickly;

c. To be quick, immediately circulated and sold so that the fish is still fresh;

d. Accelerate or shorten the circulation of fish.

However, there is a negative side or even contradictory to the Regional Regulation, that is based on Part Seven of Regulation No. 4 Year 2009 of Rembang Regency About Management of Fish Auction Place, especially the procedure of Collection/Levy Article 16 states:

1) Retribution collection cannot be pushed.

2) Levies as referred to in paragraph (1) shall be levied on the basis of SKRD or other equivalent documents.

Then Part Four on Principles and Objectives in Stipulation of Structure and Amount of Rates Article 13 states:

1) The principles and objectives in determining the amount of Levy rates are based on the objective of obtaining proper benefits.

2) Decent profit as referred to in paragraph (1) shall be the profit earned if the service of providing TPI facilities is efficiently and market-oriented.

Then Part Five regarding the amount of Levy Rates as per the Article 14:

1) Each TPI facility provision facility shall be levied at 3.50\% (three point fifty percent) of the auction values as referred to in article 12 .

2) The levies as meant in paragraph (1) shall be imposed on fishermen as fish sellers of $2.10 \%$ (two point ten percent) and traders as fish buyers of $1.40 \%$ (one point forty percent).

Then Article 15 on the place and Authority of Collection:

1) The levy shall be levied at the place of retribution object within the Sea Department environment. They may be appointed as a mandatory retribution levy as meant in paragraph (1) stipulated by the Regent

2) The Revenue Office for Financial Management and Regional Assets of Rembang Regency is the levy collector coordinator as required in paragraph (1).

3) The provision of Juragan take the share-sharing ration is more than their agreement with various excuses. Finally the Pandega relented, because they are aware of the need to stock to go to the sea. In fact, often the results of sea fishing is not proportional to the stock received, because the results are smaller or fewer than the stock that has been brought/received so that eventually these crew are indebted and even up to the hundreds of millions of Rupiahs.

\section{CONCLUSION}

Conditional injustice in the sense of saving the product from the fish aims to maintain the quality of the catch fish itself, so that fish catching the Puerse Seine ship directly put into the Freezer without going through the process of scales and without separation of fish species. Levies that should not be allowed to pay in bulk without prior knowledge of the weight of fish catch and fish species, it is finally still done with the reason for the efficiency of time 
and save the fish catch. The actual auction is a duty intended to maintain and provide a reasonable profit, ultimately deviate, forced to do with a conditional purpose to save the fish catch to stay fresh up to the consumer.

Not transparent Juragan to Pandega against the value of loans or supplies to the crew of the crew despite the disappointment, but apparently they are still acceptable for what it is because without the aid of the stock they will not get the results of fishing and do not get the provision to go to sea or economy family stock.

\section{BIBLIOGRAPHY}

Abdul Salam, 2011, Filsafat Hukum, Perspektif Sejarah, PTIK, in Kholis Roisah, Dynamics of Intellectual Property Protection in a Global Claim, Jakata.

Handbook of Technical Implementation Unit of Fishery Business Management and Development, Rembang Regency Government Marine and Fishery Service Office.

Cherul Umam, dalam Kompas on 23 March 2007.

Mariam Darus Badrulzaman, 1981, Pembentukan Hukum Nasional dan Permasalahannya (Written Collection), Alumni, Bandung.

Kompas, Saturday, on 25 February 2012, (Fishermen Ask for Cheap Solar Price).

Regional Regulation Number 4 Year 2009 of Rembang Regency About Management of Fish Auction Sites.

Syahrial Syarbaini, 2011, Pendidikan Pancasila (Implementasi Nilai-nilai Karakter Bangsa), Ghalia Indonesia, Jakarta.

Soebekti dan Tjitrosudibio, 1983, Kitab Undang-undang Hukum Perdata, Pradnya Paramita, Jakarta.

Syahrial Syarbaini, 2011, Pendidikan Pancasila (Implementasi Nilai-nilai Karakter Bangsa), Ghalia Indonesia, Jakarta.

Sayogyo, Cendekiawan Pembela kaum lemah, Gatra No.20 Tahun XVIII, 22-28 Maret 2012 